The Galbraiths' protégé also grew to be a full-antlered beauty. We knew him well. and it was with deep regret that we learned he had been found dead near his home last fall. For the past three years he had rambled about the neighbourhood freely and he had come to know the folks who gave him a handout. He always recognized the Galbraith farm as his home and returned there regularly or when he was agitated, probably after being chased.

One of his favourite recreational stunts was to suddenly leave the cattle with whom he fraternized and race for home, clearing the yard fence, to chase the barnyard forwl at full speed and send them helter-skelter. Then he would leap over the fence again and go back to the leisurely, sedate company of the cows. He never caused a casualty among the chickens.

In death he showed signs of having been in a conflict, possibly with one of his own kind. A horn was broken off at the base and his head was badly festered. The slough where he died was his favourite watering and resting place and he may, in a weakened condition, have endeavoured to reach the receding waters and got bogged down in the mud.

\section{DEER MAKES A SUICIDE JUMP OFF NIPAWIN BRIDGE}

On June 22, 1958, it was reported to me that a male deer was killed instantly when jumping off the $\mathrm{Ni}$ pawin traffic bridge. Mr. Ostberg, of Ostberg Equipment, witnessed the proceedings along with another person whose name is not known at the present time.

When Mr. Ostberg approached the bridge from the north with his vehicle he observed the deer running on the bridge ahead of the car. At this moment another car approached the bridge from the south entrance causing the deer to jump clear of the on-coming traffic. Mr. Ostberg states that the deer died instantly when hitting the water and was last seen drifting downstream.

That is something that seldom occurs to wildlife, and I thought it would be of some interest to you.
-G. J. Pederson, Cons. Officer Dept of Nat. Resources, Nipawir Sask.

\section{INGENIOUS FOX}

Over 60 years ago I was workin on Mrs. Jchn Young's ranch, nea the present town of Kamsack. On day, Mr. Young saw a fox amons his sheep in the yard. Nearby there was an unused chicken hous with a hole in the roof. The for entered the chicken house and $\mathrm{Mr}$ Young picked up a stick and ran ir after it. He thought he had that fo cornered and tried his hardest to hit the animal with his stick, bu each time he brought the stick dow Mr. Fox was just not there. Th fox took in the situation and notice that Mr. Young was standing jus beneath the hole in the roof. $H$ jumped up on Mr. Young's bacl and hopped out of the hole and away! Who says that wild animal don't think when met with a nev situation.-P. Fraser, Kelvington Sask.

\section{BARKING TIMBER WOLF}

Have you ever heard a timbe: wolf bark? I heard one on an Oc tober evening last year. I was stand ing in my rowboat deep in a creek On my right was a wooded hill, or my left a small rocky island with : dense bush, and before me oper sandbanks. A pack of young timbe wolves were howling in the hill and coming in my direction. Wher they reached the woods above the sandibanks they stopped, so near to me that I could recognize individua voices in the chorus. In the fading light, I saw quick movements at the far end of the sand, and a shadow seemed to cross the banks opposite me and disappear in the bush or the small island. Shortly after that a single wolf howled in the bust and at once the sand of the bank: was alive with the black bodies a young wolves running. I shot in the middle of the running pack. They separated at once; some reached the island and the rest turned back to the woods. Directly opposite me ir the bush a wolf howled, and ther I was surprised to hear the how: change into an angry snarl and bark. like that of a very angry dog. He was still barking as I rowed away -A. Baltz, Prince Rupert, B.C. 